\title{
Exploring the human gut microbiome
}

Jun Wang

From Beyond the Genome: The true gene count, human evolution and disease genomics

Boston, MA, USA. 11-13 October 2010

Published: 11 October 2010

doi:10.1186/gb-2010-11-S1-I17

Cite this article as: Wang: Exploring the human gut microbiome.

Genome Biology 2010 11(Suppl 1):117.

- Convenient online submission

- Thorough peer review

- No space constraints or color figure charges

- Immediate publication on acceptance

- Inclusion in PubMed, CAS, Scopus and Google Scholar

- Research which is freely available for redistribution 